\title{
An Interpretive Analysis on the Heritage Values and Morphology of Tea Cultural Landscape: A Case Study on Khakiachara Tea Estate, Sreemangal, Bangladesh
}
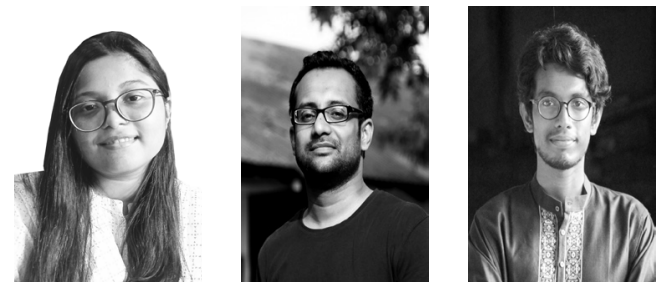

Sadiya Afrin Mazumder ${ }^{1}$, Assoc.Prof.Dr. Kawshik Saha², Mahinul Haque $^{3}$

Department of Architecture, Shahjalal University of Science and Technology, Sylhet, Bangladesh ${ }^{123}$

sadiaasworna@gmail.com¹, kawshik.saha@gmail.com², mahinul.haque@gmail.com ${ }^{3}$

https://orcid.org/0000-0002-4372-1612

https://orcid.org/0000-0003-1886-2445

https://orcid.org/0000-0003-2277-7809

Received: 28.06 .2021

Accepted: 18.10 .2021

DOI:10.17932/IAU.ARCH.2015.017/arch_v07i2003

\begin{abstract}
The Cultural Landscape of the tea garden is a metamorphosed expression of the natural landscape, which has evolved with time by setting up the tea industries in topographically suitable areas and influenced by the activities of the tea community. It is essentially a unique set of intangible and tangible features, which is not getting tourists' and researchers' perception due to lack of proper management. The study analyzes a territory in the Khakiachara tea garden, Sreemangal, and aims to showcase the existing natural and cultural setting of tea gardens by proposing an interpretive guideline. The major steps of this research are to identify the Heritage values and morphology by on-site survey and data collection, categorize them by audience perception analysis and develop a network of Cultural Heritage resources. The result of this study may provide a heritage management guideline, serve as a possible mechanism to maintain natural and cultural eco-system and boost economic development.
\end{abstract}

Keywords: Cultural landscape, cultural heritage, heritage values, heritage preservation, morphology, intangible heritage, tangible heritage.

\section{Çay Kültü̈rel Peyzajının Miras Dĕ̆erleri ve Morfolojisi Üzerine Yorumlayıcı Bir Analiz: Khakiachara Çay Bölgesi Alan Çalışmasi, Sreemangal, Bangladeş}

Öz: Çay bahçesinin Kültürel Peyzajı, çay endüstrilerini topografik olarak uygun alanlarda kurarak ve çay topluluğunun faaliyetlerinden etkilenerek zamanla gelişen doğal peyzajın başkalaşmış bir ifadesidir. Esasen, uygun yönetim eksikliğinden dolayı turistlerin ve araştırmacıların algısını alamayan benzersiz bir soyut ve somut özellikler kümesidir. Çalışma, Khakiachara çay bahçesi Sreemangal〉daki bir bölgeyi analiz etmekte ve çay bahçelerinin mevcut doğal ve kültürel ortamını sergilemeyi amaçlamaktadır. Araştırma metotları olarak yerinde anket ve veri toplama kullanılmıştır. Böylece miras değerlerini ve morfolojisini belirlemeye, bunları izleyici algı analizi ile kategorize edilmeye ve bir Kültürel Miras kaynakları ağ l geliştirilmeye çalışılmıştır. Bu çalışmanın sonucu, bir miras yönetimi rehberi sağlayabilir. Doğal ve kültürel eko-sistemi sürdürmek ve ekonomik kalkınmayı hızlandırmak için olası bir mekanizma olarak hizmet edebilir.

Anahtar Kelimeler: Kültürel peyzaj, kültürel miras, miras değerleri, mirasın korunması, morfoloji, somut olmayan miras, somut miras. 


\section{INTRODUCTION}

Morphology of any particular region can be described as a summary of the interplay between landscape values, associated people and land-use practices. Tea Cultural Landscape with a synthesis of unique tangible and intangible features have tourism potentials and user demands, which is not given relative importance as a valuable heritage [1]. Among the tangible features, the tea cultural landscape has significant attractions such as historic buildings of the British colonial period, Tea factory, and temporary house structures of the tea community. The large-scale tea plantation area is the core substantial feature that attracts the tourists or visitors the most. Tea Cultural Landscape has various aspects of the material culture and intangible resources like their unique lifestyle, community activities, oral traditions, etc. as significant tourist attractions that are associated with historic buildings and sites of tea gardens, tea trading, and tea consumption [2]. These significant features can also explain the story of tea community and illustrate the morphology of tea garden areas, which are worthy of exploration and getting promoted [2]. Interpretation is considered as the most useful tool for this [3]. This article focuses on bringing out these valuable heritage resources through identifying and highlighting them keeping in their existing form so that they can get proper attention of planners and other researchers, which may help to enhance the decision-making process for future development planning by means of explanation of the local lifestyle and the pattern of cultural attribute and create positive influence on the physical settings of the local area [4].

\section{LANDSCAPE FORMATION AND MORPHOLOGY OF TEA CULTURAL LANDSCAPE}

Generally, tea agricultural landscape can be defined as a part of the natural landscape system that evolved and developed somewhat organically in the context of surrounding natural elements [5,6]. A tea garden requires specific landscape formation in order to grow and sustain; and this unique natural landscape setting defines and characterizes the tea cultural landscape around the tea garden over time. The tea industry blends with the natural landscape formation of the tea garden; and is heavily influenced by the surrounding tea community and their activities. Over a span of time, cultural phenomenon occurs through the exchange of human values within the specific cultural area, in terms of technological development and landscape design, which represent the very essence of the tea agricultural landscape. In terms of tangible heritage, the tea cultural landscape is formed by a few natural and materialistic components; such as: tea factory, areas of tea plantation, connective paths and roadways, bungalows for accommodation purpose, housing facilities for tea community (known as 'coolie-line') and their community spaces etc. [1]. In terms of intangible cultural heritage, tea cultural landscape includes unique flavour of local traditions, skills, arts, music, dance, various cultural performances and rituals. Evidently, it can be assumed that a very unique cultural tradition develops, sustains, flourishes and thrives over a long period of time in the close premise of a tea cultural landscape [6]. The various transformation phases (Figure 1) of a natural landscape setting turning into the tea cultural landscape can be examined and verified as a distinguished example of cultural landscape according to the criteria mentioned in "Operational Guidelines for the Implementation of the World Heritage Convention: Criteria (paragraph 77)". Generally, the landscape formation of a hilly area or a mountainous site is suitable for developing a tea estate. The tea factory is placed right next to the main road for easy transportation and communication. Major portions of the labour community live adjacent to the tea factory, while other labour houses are scattered throughout the plantation areas, for maximum work efficiency in the estate (Figure 1). Labours sometime grow and harvest paddy in the open fertile arable land by their houses. The natural water streams alongside the hilly terrain (known as Charas) are used by the community to fulfil their need of water. Gradually, the labours build their community spaces at a suitable central location in the estate ground. Usually, the staff quarters or the bungalows are built at a higher elevation than the plantation terrace for a few strategic reasons, such as: easy monitoring and proper governance, as well as provide basic protection to the estate settlements. The transformation phases of the natural areas transforming into tea cultural landscape are depicted below. 


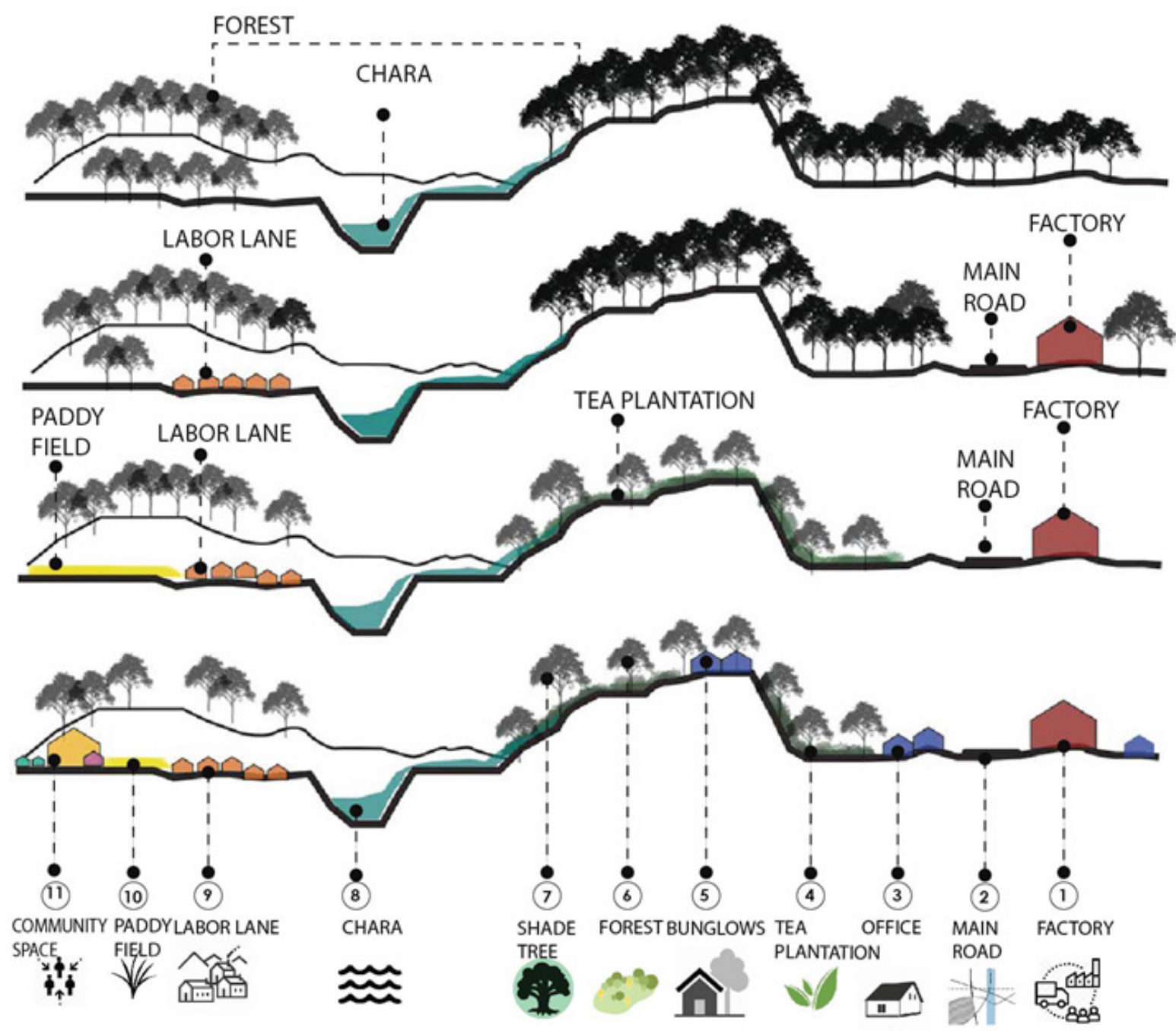

Figure 1. Transformation Phases of the Natural areas becoming the Tea Cultural Landscape

\section{CULTURAL LANDSCAPE AND VALUES}

A cultural landscape can be defined as a reflection of the culture and the living traditions of the people inhabiting it. This reflection and association developed by the close relationship between the tangible and intangible aspects of landscape over time [5]. "Cultural landscapes are illustrative of the evolution of human society and settlement over time, under the influence of the physical constraints and/or opportunities presented by their natural environment and of successive social, economic and cultural forces, both external and internal [5]".

Cultural Landscape of any region must be seen possessing significant tangible or intangible values, associated with the activity performed or practiced by its inhabitants. These values can be classified by the terms aesthetic, archaeological, architectural, commemorative, functional, historical, landscape, monumental, scientific, social, spiritual, symbolic, technological, etc.[7]. Heritage values have been an important factor in the management process of heritage protection of different significant heritage collections, buildings, archaeological sites, landscapes and intangible expressions of culture, such as traditions [3]. 


\section{MATERIALS AND METHODS}

The discussion on the cases of heritage interpretation plan develops a guideline to create a methodological framework by incorporation with the consideration of the site context and the goals of the study. Essentially, the study includes two broad goals: (1) To showcase and promote the existing Natural and cultural setting of tea garden areas; and (2) To provide a future management guideline for Cultural Landscape conservation; To achieve these goals this research a conceptual methodological framework is prepared. At first heritage significance of the region is justified by theoretical analysis, and then an action plan is prepared after on-site survey and questionnaire survey, where visitor experience objectives are identified by value identification mapping and value analysis of the study area. The next step was categorizing the identified resources, which is an organized outline of heritage resources and can effectively showcase the region's story. At the end of the study we may achieve an existing connectivity or network of the most highlighting features of the tea garden which can be promoted by heritage interpretation. The overall research was conducted by 5 major stages:

1) The map containing the ecological structure of the study area and its connectivity with the administrative zone were collected from the concerned institutions.

2) The traditional living harmony forming the historical landscape, heritage values, historical buildings (mosques, Temples, Nachghar, Tea factory, etc.), demographic structure and cultural texture belonging to the study area within the scope of the study field were obtained from the related publications and official documents by searching the literature.

3) The evaluation strategy for assessing the heritage values is decided by the audience's perception. As audiences, the authors considered the local community or habitats who live or work here and also the tourists and visitors who generally visit the area as a tourism destination. The questionnaire survey was conducted by interviewing 100 people from the community people and visitors and 50 people from the administrative zone. An Information form was prepared to evaluate the existing heritage resources by identification of the heritage values. In the information form, oral data was gathered by questioning the current natural scenario, living facilities, physical and structural characteristics, infrastructure and transportation conditions, agricultural activities and scientific development, population and population movement of the area, educational, socio-cultural and economic situation of the people living in the area, their customs and traditions, handcrafts from the past till today, folkloric characteristics, current problems in the area, tourism facilities and resources, current situation of the other historical and cultural resources. Thus, the contributions of the people living in the area to the cultural landscape were determined. Besides, the interventions, particularly human interventions, which caused changes in the landscape of Khakiachara Tea Garden and its surroundings, were questioned[11].

4) In order to show the cultural landscape values of the area, oral data obtained by means of the information forms were analyzed. In the method of analysis, 12 criteria were used to determine the cultural landscape. These criteria were obtained by a literature survey. They were: historical importance of the region, current historical-archeological elements and sites in the area, local architecture, handicrafts, religious places, festivals and festivities, agricultural industry, transhumance tradition, associations and cooperatives, non-formal education, monumental objects and areas to be protected. A qualitative evaluation was carried out depending on the existence of these criteria within the scope of the study field. Since there was some common distribution of the cultural values when the entire area was considered, qualitative evaluation was carried out rather than quantitative one. Therefore, after analyzing the whole area six heritage values were identified. They are: Aesthetic, Historic, Scientific, Social, Symbolic and Spiritual values.

5) In the direction of these data obtained in the final stage, some maps were produced showing how the cultural values together effectively function in the study area. 


\section{RESULTS}

\subsection{Heritage Value Identification of the Study Area: A Case Study on Khakiachara Tea Garden, Sreemangal}

The study selected the khakiachara tea garden and its surrounding area (Figure 2) as a sample of "Tea Cultural Landscape" which is located at Sreemangal, popularly known as the "Tea Capital of Bangladesh".
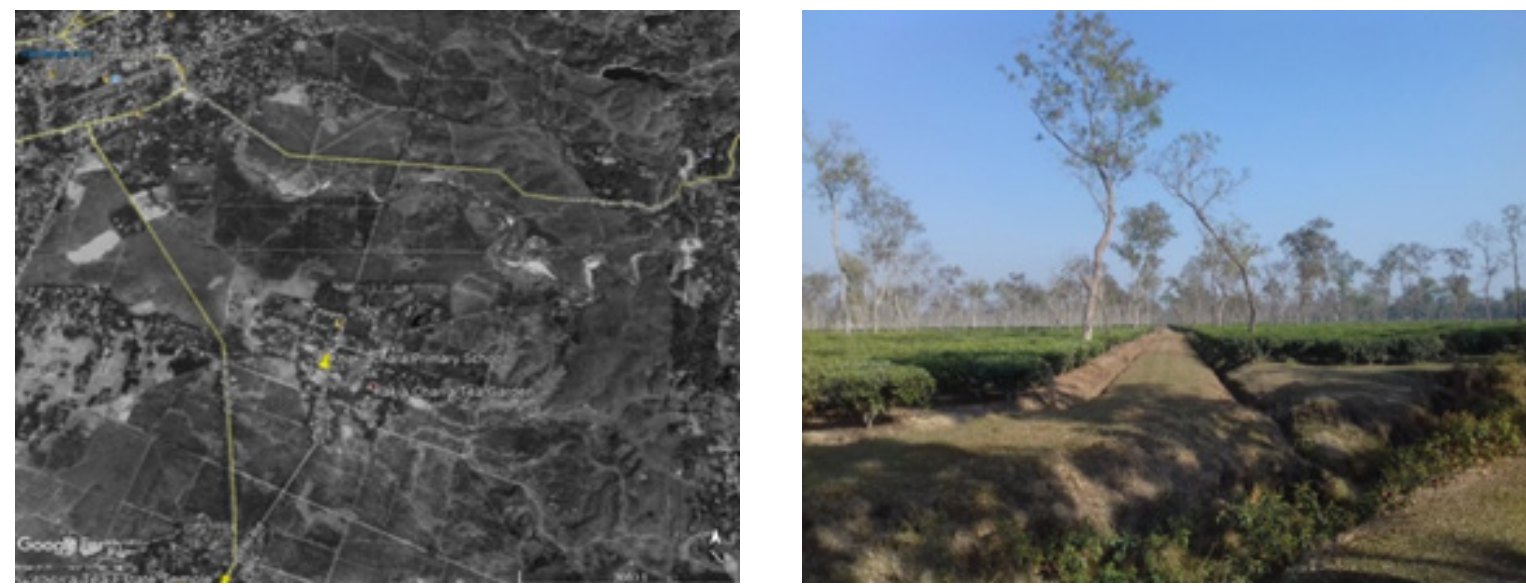

Figure 2. Map showing Study Area: Khakiachara Tea Garden (Developed by Authors)

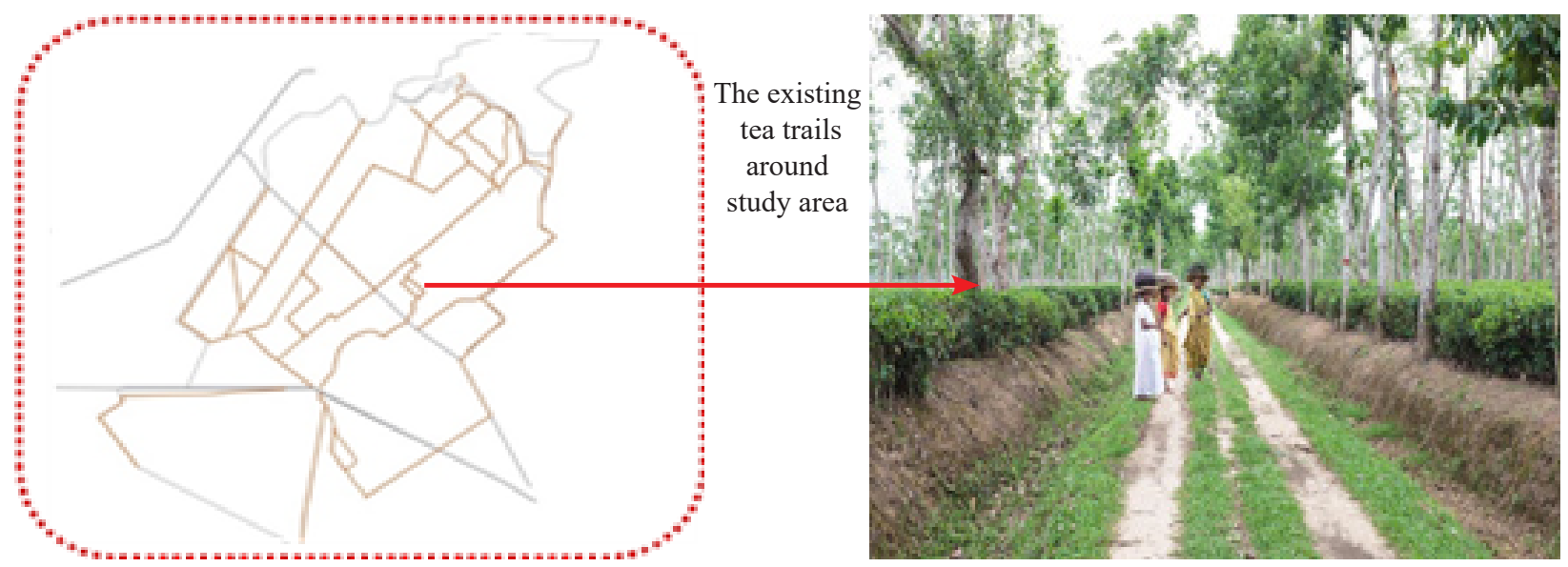

Figure 3. Map showing the Existing Tea Trails

Sreemangal is a upazila in Moulvibazar district of Sylhet region, which has become one of the dynamic centers of all activities related to trade, economy and distribution of Tea Industry of Bangladesh. This area has also developed a diverse collection of ethnic groups, who are closely associated with all types of commercial activity related to the tea industry like tea growing, producing, processing, and selling. At past times they were majorly illiterate labourers belonging to lower and downtrodden communities. When in 1837 British started the tea plantations in Assam and recruited huge number of poor, hard pressed and ignored community such as Santhal, Munda, Oraon, Khond, etc. from famine and poverty-stricken areas of Bihar, Odisha, Madhya Pradesh, Uttar Pradesh, Andhra Pradesh and West Bengal having diversity in respect of their language, tradition, culture, religion and social background on false promises such as higher wages, better life, better living conditions and at the end of contract period they would be free to go [12]. 
This vibrant group of people has harmonized themselves into a conjoint territory and developed a sustainable settlement pattern by sharing their norms, beliefs and practices, where together they have originated their distinct identity as the Tea community.

The first step of this research is to identify the heritage resources in the tea cultural landscape of Khakiachara tea garden. The following map is showing the identified heritage resources, which is produced by collecting data from google earth combining them with physical survey with interviewing 150 people from the local tea community and visitors and 50 people from the administrative sector of tea industry.

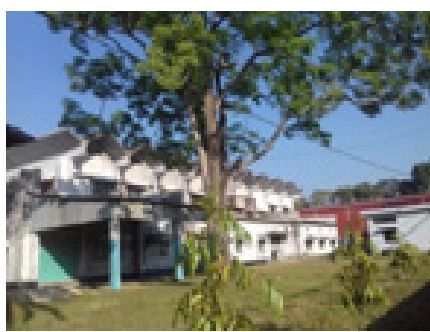

(a)

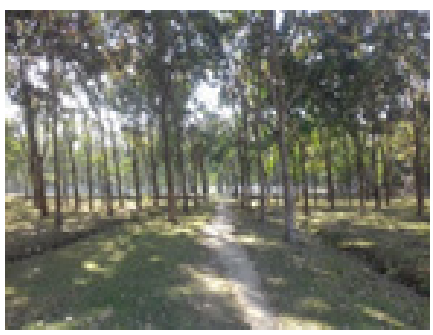

(b)

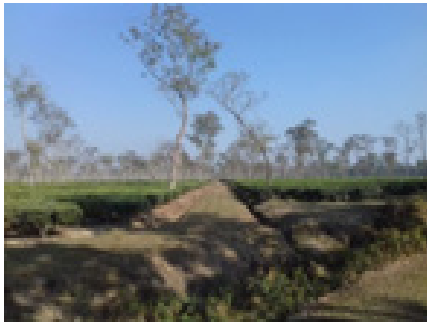

(c)
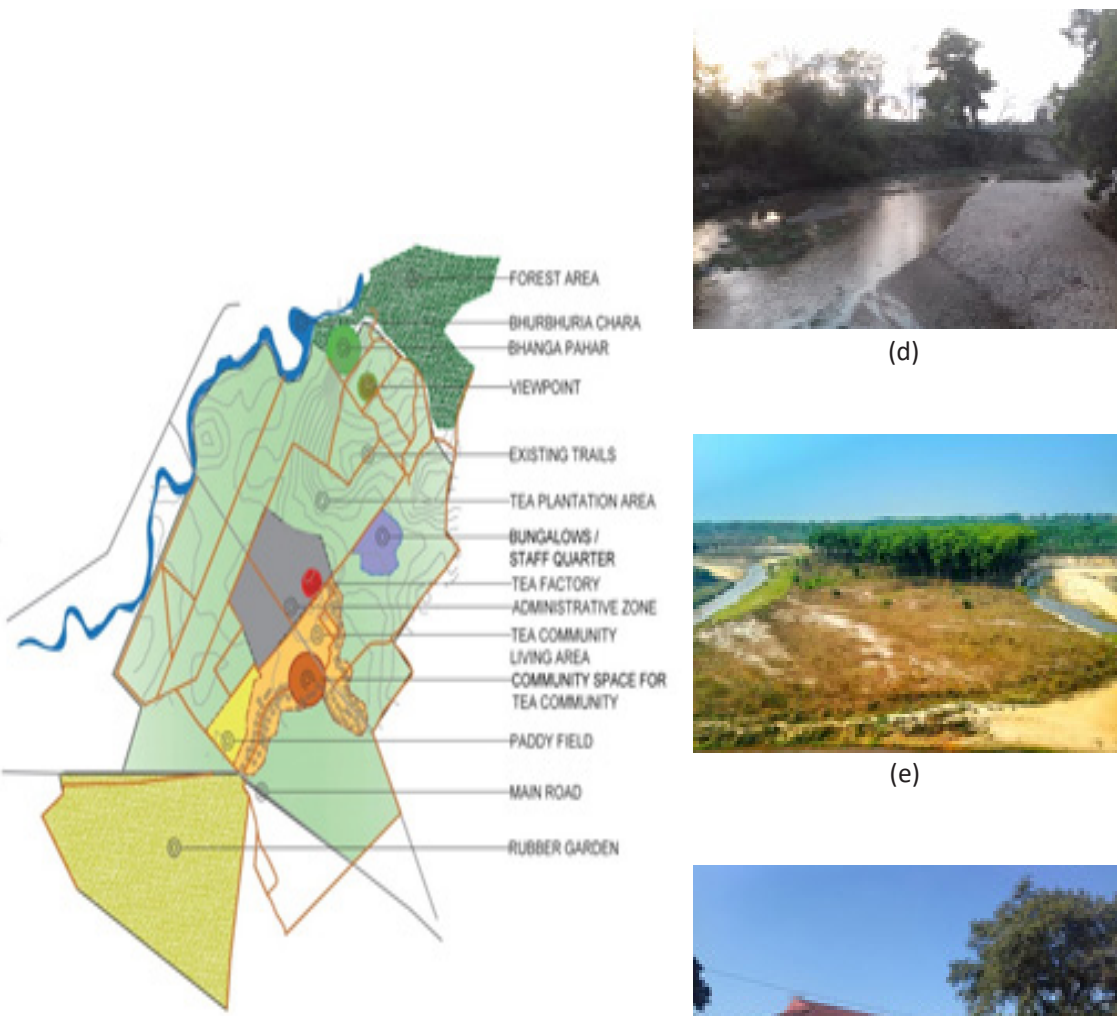

(d)

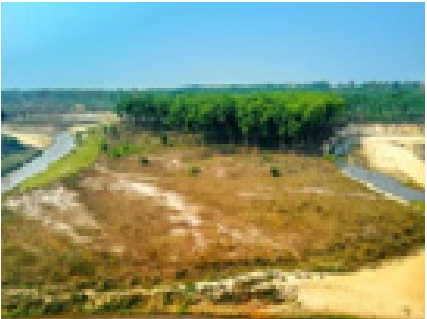

(e)

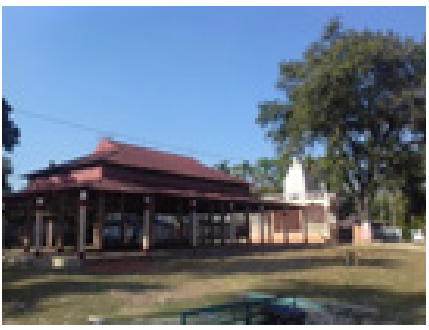

(f)

Figure 4. Identified Heritage resources of study area

\subsection{Value Analysis according to User Perception}

According to audience perception study, the identified and significant heritage resources are categorized in the table above. Firstly, the value elements were placed under three broad categories. They are: Tangible Natural Heritage Resources, Tangible Cultural Heritage Resources and Intangible Cultural Heritage Resources. Table 1 shows that, all the Tangible Natural Heritage Resources can be divided into two individual types. They are the plantation area and other natural forms like Bhurbhuria Chara (Figure 4.d), Bhanga Pahar (Figure 4.e), and Natural Viewpoint etc. 
Table 1. Categorizing Tangible Natural Heritage Resources along Khakiachara Tea Garden

\begin{tabular}{|c|c|c|c|c|c|c|c|c|}
\hline \multirow[t]{3}{*}{ Values } & \multicolumn{8}{|c|}{ Tangible Natural Heritage Resources } \\
\hline & \multicolumn{4}{|c|}{ Plantation Areas } & \multicolumn{4}{|c|}{ Natural forms } \\
\hline & 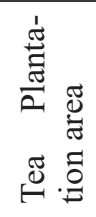 & 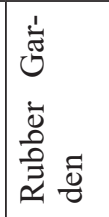 & $\begin{array}{l}\frac{n}{0} \\
0 \\
i \\
\frac{\pi}{\pi} \\
0 \\
0\end{array}$ & 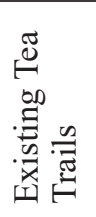 & 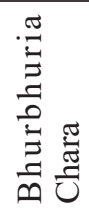 & 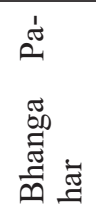 & 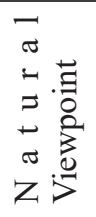 & 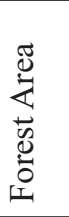 \\
\hline Aesthetic & $\sqrt{ }$ & $\sqrt{ }$ & $\sqrt{ }$ & $\sqrt{ }$ & $\sqrt{ }$ & $\sqrt{ }$ & $\sqrt{ }$ & $\sqrt{ }$ \\
\hline Historic & & & & & $\sqrt{ }$ & & & \\
\hline Scientific & $\sqrt{ }$ & $\sqrt{ }$ & $\sqrt{ }$ & $\sqrt{ }$ & $\sqrt{ }$ & $\sqrt{ }$ & $\sqrt{ }$ & $\sqrt{ }$ \\
\hline Social & & & & $\sqrt{ }$ & & & & \\
\hline Symbolic & & & & & & $\sqrt{ }$ & & \\
\hline Spiritual & & & & & & & & \\
\hline
\end{tabular}

The audience perception result shows that all the natural tangible heritage elements have significant aesthetic and scientific values for their scenic beauty and important contribution in scientific research areas.

Table 2. Categorizing Tangible Cultural Heritage Resources along Khakiachara Tea Garden

\begin{tabular}{|c|c|c|c|c|c|c|c|c|c|c|}
\hline \multirow[t]{3}{*}{ Values } & \multicolumn{10}{|c|}{ Tangible Cultural Heritage Resources } \\
\hline & \multicolumn{5}{|c|}{ Community spaces of Tea community } & \multicolumn{5}{|c|}{ Building structures of Tea Estate settlements } \\
\hline & 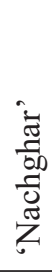 & $\begin{array}{l}\stackrel{0}{\vec{\sigma}} \\
\overrightarrow{0} \\
\stackrel{0}{\Sigma}\end{array}$ & 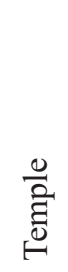 & $\begin{array}{l}\overline{0} \\
\text { 弟 }\end{array}$ & 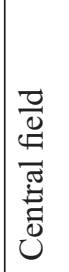 & 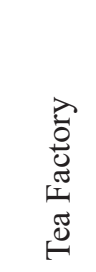 & 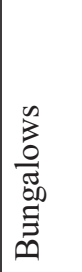 & 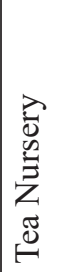 & 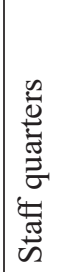 & 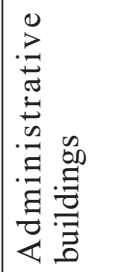 \\
\hline Aesthetic & $\sqrt{ }$ & $\sqrt{ }$ & $\sqrt{ }$ & $\sqrt{ }$ & & & $\sqrt{ }$ & & & \\
\hline Historic & $\sqrt{ }$ & & & & & $\sqrt{ }$ & $\sqrt{ }$ & & $\sqrt{ }$ & $\sqrt{ }$ \\
\hline Scientific & $\sqrt{ }$ & & & & & $\sqrt{ }$ & $\sqrt{ }$ & $\sqrt{ }$ & $\sqrt{ }$ & $\sqrt{ }$ \\
\hline
\end{tabular}




\begin{tabular}{|l|c|c|c|c|c|c|c|c|c|c|}
\hline Social & $\sqrt{ }$ & $\sqrt{ }$ & $\sqrt{ }$ & $\sqrt{ }$ & $\sqrt{ }$ & $\sqrt{ }$ & & & & \\
\hline Symbolic & $\sqrt{ }$ & $\sqrt{ }$ & $\sqrt{ }$ & $\sqrt{ }$ & $\sqrt{ }$ & & & & & \\
\hline Spiritual & & $\sqrt{ }$ & $\sqrt{ }$ & $\sqrt{ }$ & & & & & & \\
\hline
\end{tabular}

The audience was highly inquisitive to contribute their opinion regarding the Intangible and Tangible Cultural Heritage values of tea garden. According to their perception, the most significant Tangible Cultural elements are found in the central community space of a tea estate. Among them the "Nachghar" (Figure 4.f) have the highest number of values and can be identified as one of the most important 'Cultural Icon' of Tea Estate. In terms of Intangible Cultural Heritage, the living style, the sense of worship and their rituals were identified containing greater heritage values.

Table 3. Categorizing Tangible Cultural Heritage Resources along Khakiachara Tea Garden

\begin{tabular}{|c|c|c|c|c|}
\hline \multirow[t]{3}{*}{ Values } & \multicolumn{4}{|c|}{ Intangible Cultural Heritage Resources } \\
\hline & \multicolumn{4}{|c|}{ Cultural activities of Tea community } \\
\hline & $\begin{array}{l}\text { Oral traditions of tea } \\
\text { community }\end{array}$ & $\begin{array}{l}\text { Living } \\
\text { style }\end{array}$ & Sense of worship and rituals & Knowledge and skills \\
\hline \multicolumn{5}{|l|}{ Aesthetic } \\
\hline Historic & $\sqrt{ }$ & & $\sqrt{ }$ & \\
\hline Scientific & & $\sqrt{ }$ & & $\sqrt{ }$ \\
\hline Social & $\sqrt{ }$ & $\sqrt{ }$ & $\sqrt{ }$ & $\sqrt{ }$ \\
\hline Symbolic & $\sqrt{ }$ & $\sqrt{ }$ & $\sqrt{ }$ & $\sqrt{ }$ \\
\hline Spiritual & & $\sqrt{ }$ & $\sqrt{ }$ & \\
\hline
\end{tabular}

\section{DISCUSSION}

\subsection{Investigation for the Existing Network of Cultural Landscape Resources with the Tea Trails}

This study is a preliminary approach to introduce tea cultural landscape as a living heritage and identifying its significant values. By preserving the existing harmony between the forms and practices the natural and cultural eco-system and landscape connectivity may be conserved. The existing network of cultural landscape resources of tea gardens may serve as a possible mechanism to boost the economic development if it is promoted through encouraging tea tourism. However, 'Tea Tourism' is not completely a new concept. It is influenced by ancient history and traditions. Tea tourism encourages appreciation of the tea landscape and 
other activities such as visiting tea shops and museums, tea tasting, demonstrations of tea production, participating in tea ceremonies and cultural events, tea featured accommodations, tea infused cuisine etc. [8].

In this study, the spatial structure of khakiachara tea garden has been analyzed; heritage resources are identified and then classified according to the value typology and user perception. Tea cultural landscape can be considered as a linear heritage [9]. By value analysis mapping; here the existing connection between the tea trails (Figure 3 ) and the heritage value elements are analyzed. The following maps are showing the heritage values through the existing tea trails by user perception analysis.

\subsubsection{Assessment of Aesthetic Values along with the Study Area}

The graph is prepared by the audience perception analysis regarding the heritage resources containing aesthetic values. According to the graph "Nachghar"(Figure 4.f) is the most prominent cultural element that has aesthetic values. "Nachghar"(Figure 4.f) is the local name of the community space of Tea Tribal community of the study area. This is a place where people of different religions and cultural backgrounds gather together during their festivals. "Nachghar" (Figure 4.f) is generally located at the center of the tea community living area. It is known from the audience analysis that every Tea estate commonly have a "Nachghar" Among the other natural elements, the tea plantation area (Figure 4.c) and the existing tea trails (Figure 4.c) were identified as the most popular aesthetic feature of tea gardens.
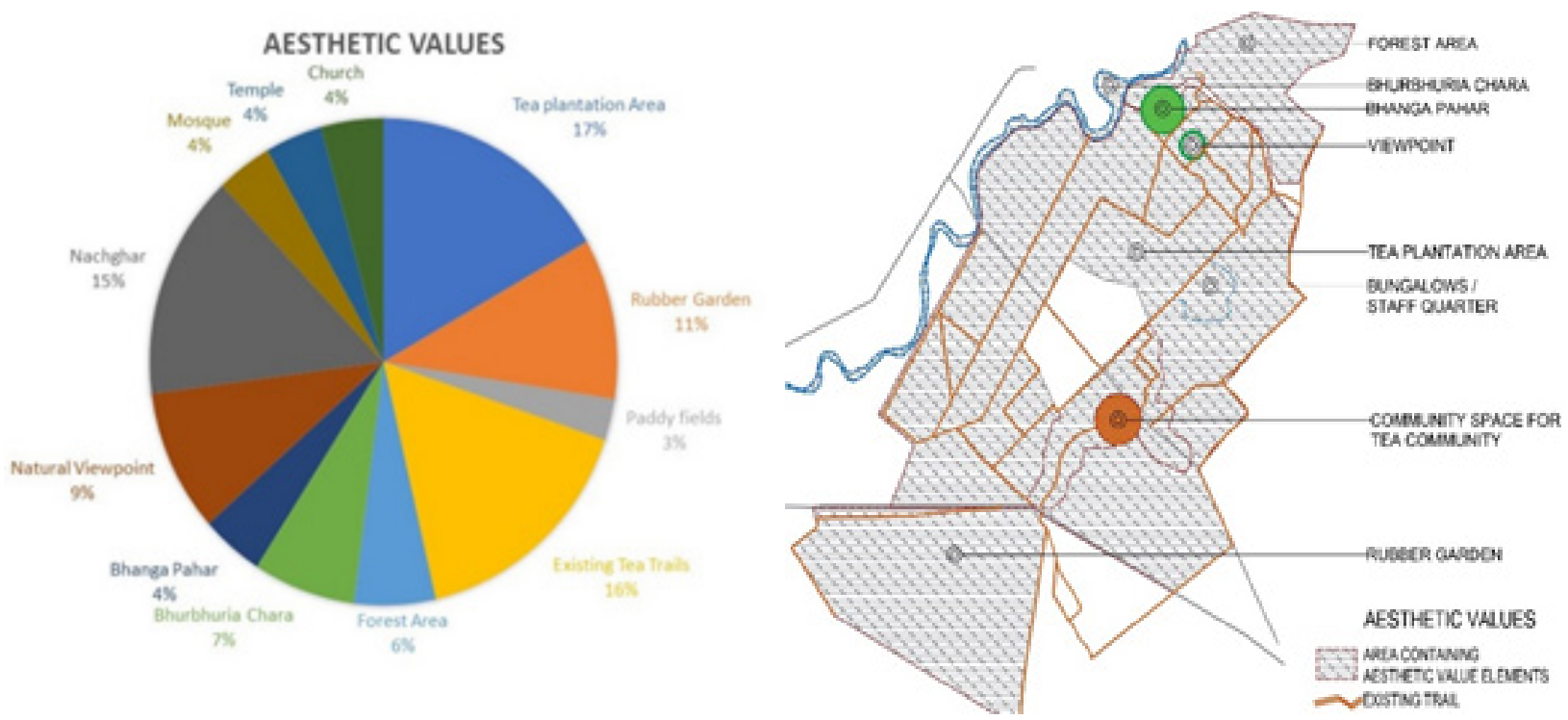

Figure 5. Graph showing assessment of aesthetic values around the study area and map showing the existing of aesthetic values with the tea trails

\subsubsection{Assessment of Historic Values along with the Study Area}

The graph shows majority of the built structures in tea estate settlement provide a connectedness with the past times. "Bhurbhuria Chara" is a unique historical tangible natural element, found in the study area. Among the tangible cultural elements "Nachghar" (Figure 4.f), Tea Bunglows, Tea Factory (Figure 4.a) are identified as the most valuable historic elements of a tea estate containing architectural style of British colonial period and mostly they were constructed during the rule of British government. The Unique Architectural style of these historic built structures reveals the origins of their present forms. 


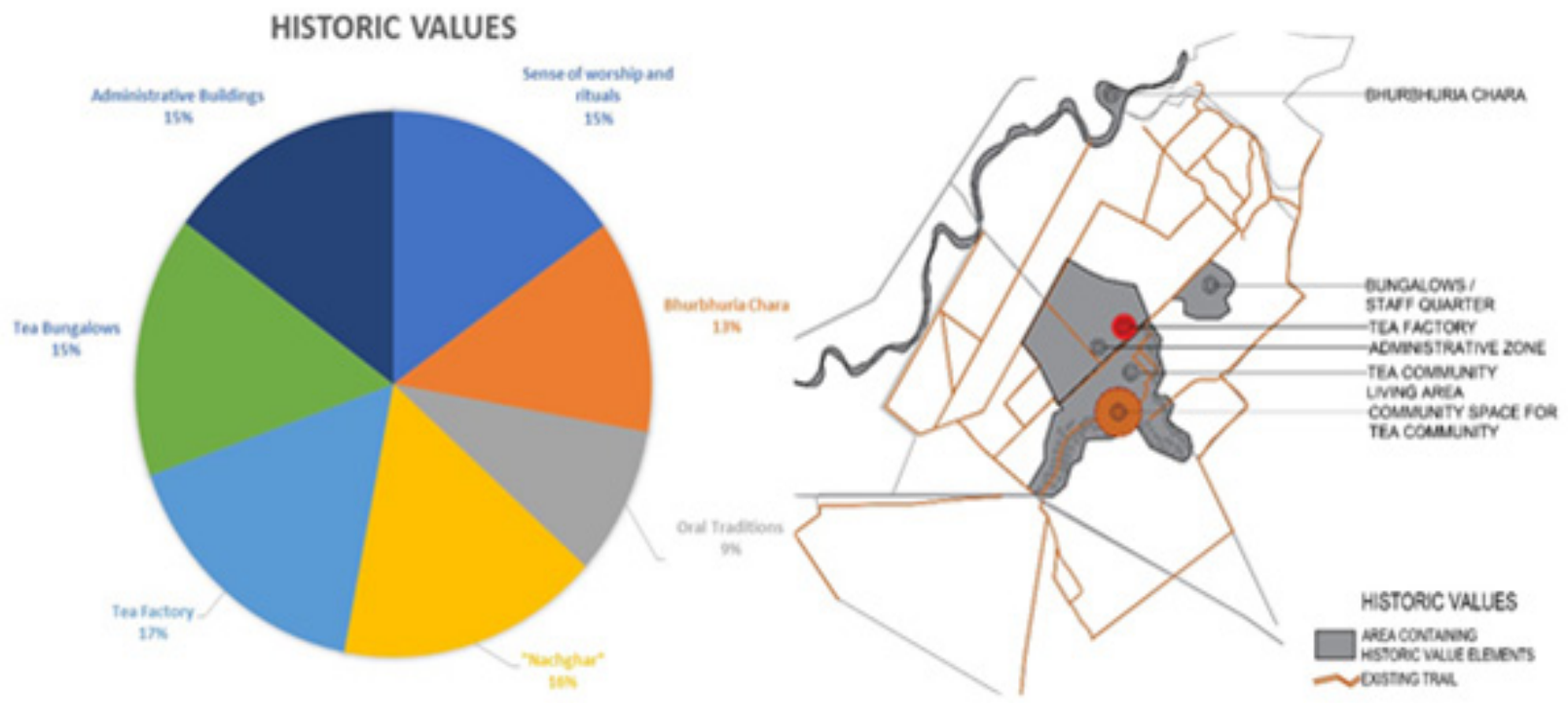

Figure 6. Graph showing assessment of historic values around the study area and map showing the existing of historic values with the tea trails

\subsubsection{Assessment of Scientific Values along with the Study Area}

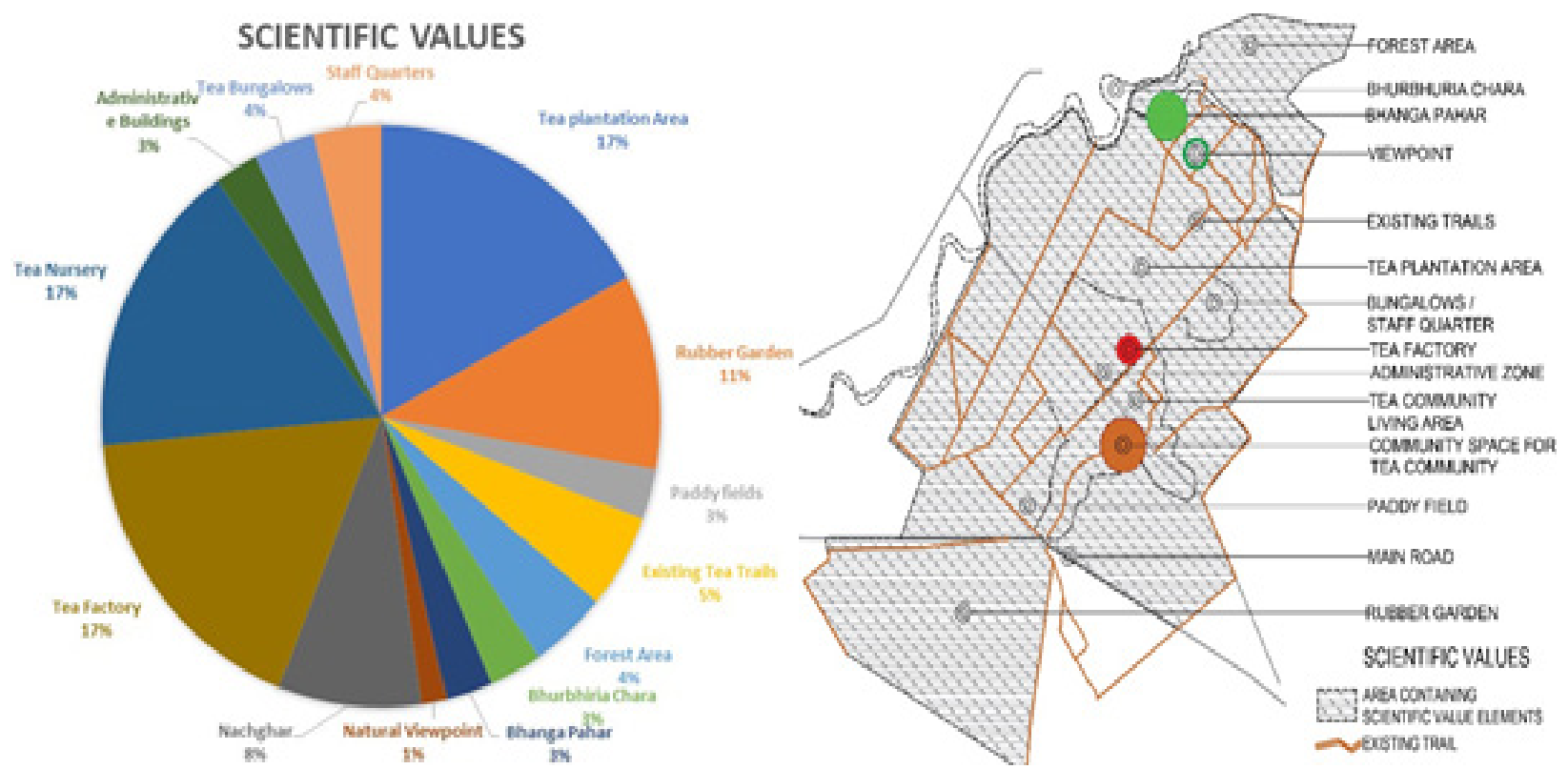

Figure 7. Graph showing assessment of scientific values around the study area and map showing the existing of scientific values with the tea trails

From the graph, it can be understood that the Tea Factory (Figure 4.a) can be considered as the most important scientific element that pulls together the whole system of a tea estate area. Tea Nursery and the tea plantation area are the key supporting elements of tea industry. The historic built forms along with the unique self-sustained cultural landscape of tea garden is an important source for scholarly study and extensive research is needed for its further development as tea industry has potential influence on our economy and also it has significant socio-cultural values. 


\subsubsection{Assessment of Social Values along with the Study Area}

The result of the graph shows that the central community space of the tea garden confines the most prominent features of tea estate settlements, which contribute to make the whole system socially sustainable. These elements make the tea estate a desirable place in which the tea community can live and work. During their festivals, they all gather around the "Nachghar" (Figure 4.f) and Central field. Their main market place generally situated beside the central field so it contains the greatest social values from others.
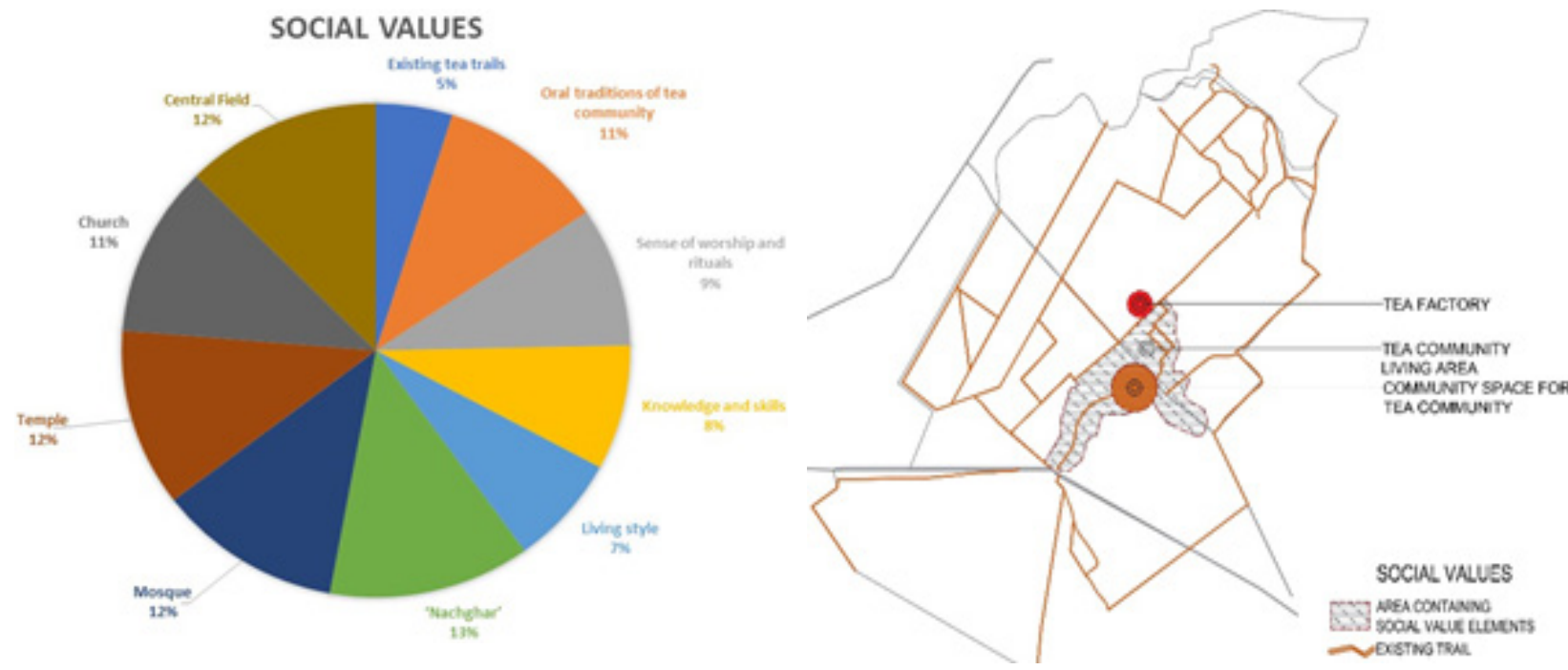

Figure 8. Graph showing assessment of social values around the study area and map showing the existing of social values with the tea trails

\subsubsection{Assessment of Symbolic Values along with the Study Area}

The graph explains that, in khakiachara tea garden, the "Nachghar" holds the highest symbolic value by virtue of its unique appearance and cultural individuality. Another identical natural landform of this area is "Bhanga Pahar". The tea community people collect colourful soil from "Bhanga Pahar" to decorate and paint their houses and walls.
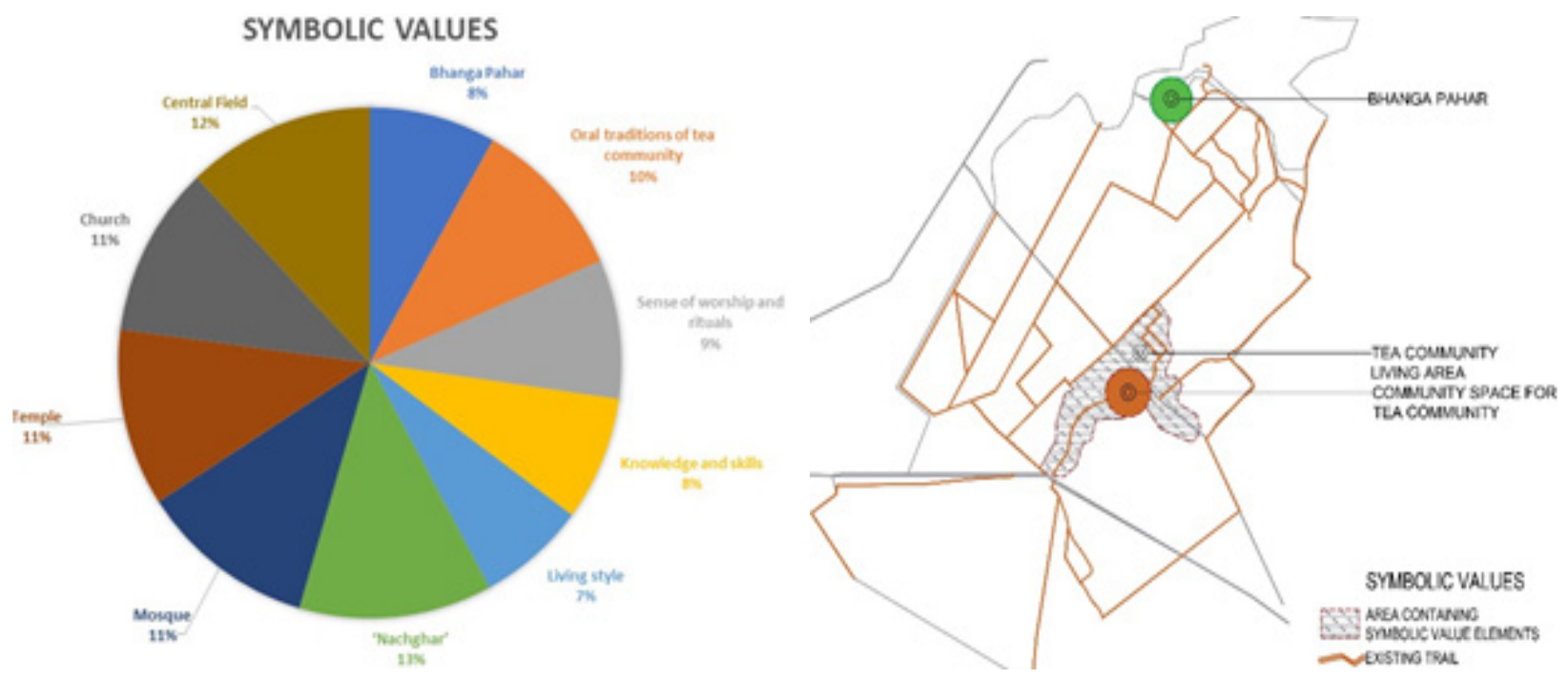

Figure 9. Graph showing assessment of symbolic values around the study area and map showing the existing of symbolic values with the tea trails 


\subsubsection{Assessment of Spiritual Values along with the Study Area}

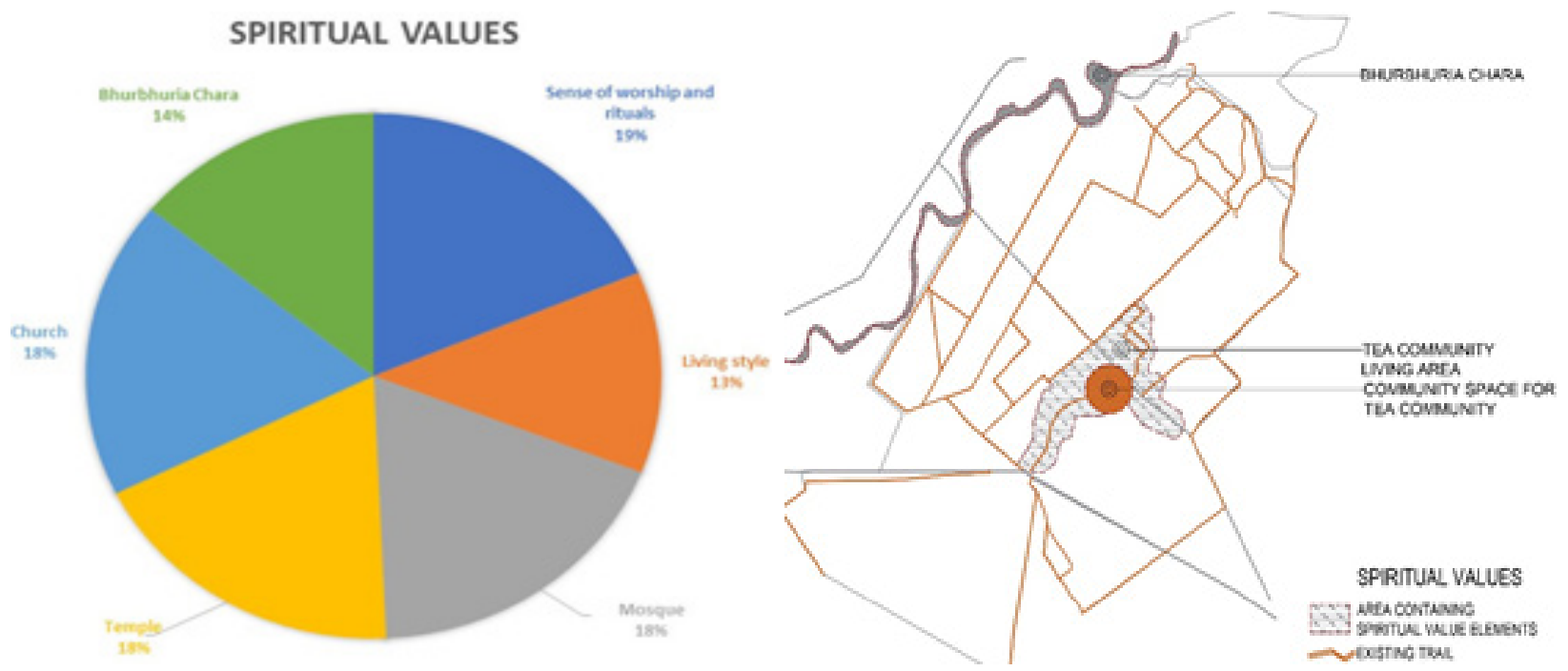

Figure 10. Graph showing assessment of spiritual values around the study area and map showing the existing of spiritual Values with the tea trails

One of the most unique and identical characteristics of Tea community people is their sensitivity about religious and spiritual aspects. Their sense of spirituality and rituals are mostly linked to the natural elements and phenomenon. For example, some particular group of people often seen to worship the natural elements like trees, water, animals etc. Even the water of "Chara" is also used during the marriage ceremonies as a part of their rituals.

\section{CONCLUSION}

Landscape connectivity and spatial structure of tea garden is a self-sustained and organically developed morphology that was formed and influenced by the inhabitants living in it. Tea agricultural landscape, itself has potentials to be recognized as valuable cultural landscape. But due to lack getting proper exposure this significant landscape is being ignored. Appropriate Conservation management of Cultural landscape can congregate people together to be conscious about their collective identity and heritage, and provide a shared local vision within a global context. Involvement of the local communities can vitalize the process, as they are the most effective guardians of the landscape heritage [10]. This paper is a primary initiative that explored for the heritage network and values in the existing tea cultural landscape in Khakiachara tea garden, which can help to realize the importance of protecting this valuable heritage and also can serve to guide detailed heritage management planning and designs. Therefore, the achievements of this study could also serve to improve the conservation systems of linear cultural landscapes.

\section{REFERENCES}

[1] Wijetunga, C. S. \& Sung, J. S. (2015). Valuing the Cultural Landscapes Past and Present: Tea Plantations in Sri Lanka. Landscape Research, 40(6), 668-683.

[2] Phipps, A. (2019). Tea and Tourism. In Tea and Tourism.

[3]Díaz-Andreu, M. (2017). Heritage Values and the Public. A Manual for Interpreting Community Heritage for Tourism. (n.d.). Journal of Community Archaeology and Heritage, 4(1), 2-6.

[4] Nunta, J. \& Sahachaisaeree, N. (2010). Determinant of cultural heritage on the spatial setting of cultural landscape: A case study on the northern region of Thailand. Procedia-Social and Behavioral Sciences, 5, 1241-1245.

[5] Mitchell, N., Rössler, M. \& Tricaud, P.-M. (2009). World Heritage Cultural Landscapes: A Handbook 
for Conservation and Management. In World Heritage Papers 26.

[6] UNESCO. (2019). Operational Guidelines for the Implementation of the World Heritage Convention Ed. 2019. July, 167.

[7] International Council on Monuments and Sites (ICOMOS). (2010) ICOMOS New Zealand Charter for the Conservation of Places of Cultural Heritage Value. ICOMOS New Zealand Charter, v, 1-11.

[8] Jolliffe, L. \& Aslam, M. S. M. (2009). Tea heritage tourism: Evidence from sri lanka. Journal of Heritage Tourism, 4(4), 331-344. https://doi.org/10.1080/17438730903186607

[9] Hui, C., Dong, C., Yuan, Z., \& Sicheng, M. (2019) Construction of Corridor of Architectural Heritage Along the Line of ZiJiang River in Hunan Province in the Background of the Tea Road Ceremony. IOP Conference Series: Materials Science and Engineering, 471(8).

[10] Rössler, M. (2006). World Heritage cultural landscapes: A UNESCO flagship programme 1992 - 2006. Landscape Research, 31(4), 333-353.

[11] Erduran, F., Uzun, O., Çetinkaya, G., Dilek, F., \& Açıksöz, S. (2012). Determination of the cultural landscape values of Lake Suğla in Turkey. Journal of Food, Agriculture \& Environment, 10(2), 949-955.

[12] Magar, C. K., \& Kar, B. K. (2016). Tea plantations and socio-cultural transformation: the case of Assam (India). Space and Culture, India, 4(1), 25-39.

SADIYA AFRIN MAZUMDER, Professional Architect \& Researcher.

Sadiya Afrin Mazumder is a professional architect and researcher from Bangladesh. She completed her Bachelor of Architecture (B.Arch) degree from Shahjalal University of Science and Technology (SUST) by taking the first place in 2019 and currently working as a practicing Architect. Her core interest in research lies into Heritage Conservation \& Management, Vernacular Architecture and Building Technology, Cultural Landscape, Sustainable Architecture and Regional Planning.

KAWSHIK SAHA, Associate Professor.

Kawshik Saha is an architect and conservation planner from Bangladesh. He is currently working as an associate professor in architecture department of Shahjalal University of Science \& technology, Bangladesh. Saha received Bachelor of Architecture degree from Khulna University on 2008. He also received Erusmus Mundus joint Master's degree in IUAV University of Venice along with University of Sevilla, and University of Azores. His current research interest includes conservation planning of cultural and natural heritage, sustainability of vernacular settlements, coastal and marine planning.

MAHINUL HAQUE, Professional Architect \& Researcher.

Mahinul Haque is an architect and writer from Bangladesh. He completed his Bachelor of Architecture (B.Arch) degree from Shahjalal University of Science and Technology (SUST) by taking the first place in 2018. He is currently working as a professional Architect, and also a freelance writer. His research interest includes Architectural History \& Philosophy, Heritage Conservation \& Management, Cultural Landscape, Sustainable Architecture and Regional Planning. 